\title{
ANALYSIS OF PRODUCTION TECHNOLOGY OF WOOD BRIQUETTES, INCLUDING COSTS AND DISTRIBUTION
}

Filip Jasiczek $^{\mathrm{a}^{*}}$, Dariusz Kwaśniewski ${ }^{\mathrm{b}}$

a Department of Production Engineering, Logistics and Applied Computer Science,

University of Agriculture in Krakow, Poland, email filipjasiczek@gmail.com, PhD student

b Department of Production Engineering, Logistics and Applied Computer Science,

University of Agriculture in Krakow, Poland, email dariusz.kwasniewski@urk.edu.pl, ORCID 0000-0002-1873-1456

*Corresponding author: e-mail: filipjasiczek@gmail.com

\begin{tabular}{|c|c|}
\hline ARTICLE INFO & ABSTRACT \\
\hline $\begin{array}{l}\text { Article history: } \\
\text { Received: August } 2019 \\
\text { Received in the revised form: } \\
\text { September } 2019 \\
\text { Accepted: September } 2019\end{array}$ & \multirow{2}{*}{$\begin{array}{l}\text { The paper analyzes the costs of production of wood sawdust briquettes, } \\
\text { manufactured by the company Brykiet-Pol2, based in Goleszó in } \\
\text { southern Poland. In addition, production technology, raw material sup- } \\
\text { ply and distribution of the finished product were analyzed. The costs of } \\
\text { producing one ton of briquettes for the four assessed variants ranged } \\
\text { from PLN } 364.8 \text { (option D) to PLN } 648.7 \text { (option A). The cost structure } \\
\text { was dominated by the purchase of raw material and depreciation of the } \\
\text { technological line. The most economically advantageous production } \\
\text { variant was option C, currently implemented in the company (produc- } \\
\text { tion costs: PLN } 458.7 \cdot \mathrm{t}^{-1} \text { ), and the proposed option D, using two bri- } \\
\text { quetting presses. The latter option increased production efficiency and } \\
\text { reduced unit costs of briquette production in a three-shift system around } \\
\text { the clock. }\end{array}$} \\
\hline $\begin{array}{l}\text { Key words: } \\
\text { briquettes, } \\
\text { production technology, } \\
\text { production costs, } \\
\text { distribution }\end{array}$ & \\
\hline
\end{tabular}

\section{Introduction}

The term biomass can be used to describe substances of vegetative and animal origin obtained from plant and forestry products, waste and residues. The term pertains also to plant and forestry production waste, as well as parts of other waste that are biodegradable. The increase in energy demand associated with climate protection increases the global use of renewable energy sources (RES), such as wind, solar, water and geothermal energy. Another is biomass, a practically an inexhaustible RES. The most important advantages of solid biomass combustion include, e.g. reduction of greenhouse gas emissions $\left(\mathrm{CO}_{2}\right.$, nitrogen and sulfur oxides), environmental protection, reclamation of degraded and agriculturally unusable land, increasing the share of renewable raw materials in the overall raw material balance, ensuring national energy security, managing surplus on the food market, creating conditions for restructuring the countryside and reviving agriculture, providing a cheap source of heat for municipal and industrial customers, a zero carbon dioxide balance during the combustion process and reducing the amount of ash compared to fossil fuels. Ecological energy sources 
Filip Jasiczek, Dariusz Kwaśniewski

also have their drawbacks, such as a large variation in the humidity range (30-60\% of humidity in biomass prior to processing into briquettes) and in physical properties, as well as limited access to the raw material, seasonality and many more (Frączek et- al., 2011 , Niedziółka et al., 2014). The developing use of biomass involves the need to increase its resources. Despite the continuous overproduction of carbon dioxide, as well as emission of dust into the atmosphere and inadequate storage of waste at landfills, Vaverkowa et alt. (Vaverkowa et al., 2018) see the potential in restoring closed landfills. This can compensate for disruptions in the ecosystem, minimize the negative environmental impact and ensure safety in further use. Afforestation of wasteland could be a source of energy biomass for the future. Plants that can be used to produce solid biofuel include energy willow, Miscanthus, Pennsylvanian mallow, etc. (Dubas et al., 2004, Wróbel and Mudryk, 2010).

The most common form of biomass processed in Poland are compact biofuels, i.e. briquettes and pellets. These are fuels built from dry, crushed plant material with high pressure, most often without the addition of artificial binders (Kowalik, 2002, Gostomczyk, 2012). The production of briquettes includes subjecting the material to three subsequent processes: drying, milling and pressing (Kuś and Matyka, 2008). Raw materials for their production are obtained from the wood processing industry (all types of sawdust, chips, wood chips, bark), from agricultural production (waste and production residues, e.g. straw of cereals) and from plantations of fast-growing plants. In Poland, energy willow, poplar, black locust, Pennsylvanian mallow and Miscanthus are grown on energy plantations (Frączek et al. 2010b).

These plants are processed into pellets or briquettes, and the main difference between them is the shape and size, selected per the purpose of biofuels. The briquettes can be cylindrical or cuboid-shaped, with four, six or eight blocks, sometimes with a hole in the center. Their sizes depend on the type of briquetting device; the length of the briquette is obtained by adjusting the dimensions of the pressing chamber. Solid cylindrical biofuel usually is 60 $80 \mathrm{~mm}$ in diameter and $40-200 \mathrm{~mm}$ in length. It is most often used in fireplaces of individual consumers. Rectangular briquettes with a square cross-section are usually $200-320 \mathrm{~mm}$ long and the height of their side is 70-100 mm. Their variety are briquettes with holes in the middle, produced using Pini-Kay type screw briquetting machines, characterized by a high degree of compression. The moisture content of such fuels is approx. $4 \%$ and their combustion process is slower than other types of solid biofuel (Frączek, 2010a).

The calorific value of briquettes depends on the raw material used and ranges from 16 to 18.5 MJ $\mathrm{kg}^{-1}$ (Kachel-Jakubowska et al., 2014, Niedziółka et al., 2007).

Detailed standards for assessing the quality of solid biofuels (low- and highly processed) can be found in PN-EN 14961-1:2010 (Solid biofuels - Fuel and class specifications - Part 1: General requirements) replaced by ISO 17225 and PN-EN 14961-22,3,4,5:2011. These documents include detailed descriptions of the quality parameters of individual forms of biofuels (briquettes, pellets, wood chips, logging residue, firewood, small straw bales, solid wood, seeds, fruit stones, shells and fibrous sludge). Descriptions included in the standards are divided into information and normative groups. In Poland, the most common briquette is the $25 / 30 / 15 \mathrm{~mm}$ cube.

In other regions of the world, briquettes are also made from rice husk and corn starch (Muazu and Stegemann, 2015). Another example may be the production of briquettes from the leaves of Cerbera Manghas (sea mango) (Sutrisno et al., 2017, Dinesha et al., 2018). 
Analysis of production...

Apart from the properties of the raw material used and the construction and operational factors of the bricketing device, a very important role is played by the briquette production costs, and the possibilities of reducing them.

\section{Purpose, scope and methodology of work}

The purpose of the work was to present the production technology of wood briquettes from sawdust, and to determine its costs, with detailed cost structure. The structure of production costs is significant and shows both dominant and negligible components. The paper also analyzes the characteristics of the supply of raw material for the production of briquettes and evaluates the distribution of the finished product.

The scope of work includes research carried out at the Brykiet-Pol2 manufacturing and trading company, located in Goleszów (Cieszyński district, Śląskie Province). The company's line of business is production of sawdust briquettes and the sale and service of briquetting presses. Raw material for production is acquired from nearby sawmills. The plant uses a briquette production line BRISUR 200 (made in Czech Republic by Briklis).

Relevant information regarding the technology and production costs, as well as the operating production line was obtained based on a structured interview with the company owner. The information also related to the supply of raw material and distribution of the finished product (the packaging method, distance to sales points, time required for delivery). The costs of producing wood briquettes were determined per one year (July 2018 - July 2019). The components of the costs structure of briquette production in the company in question include costs of purchasing the raw material, costs of production, of premises rental, drying, depreciation of equipment, costs of maintenance and repairs, costs of electricity, costs of employee remuneration, packaging and in-house transport of sawdust.

The analysis carried out in the course of research included four variants:

- variant A: single-shift work system, production line capacity of $250 \mathrm{~kg} \cdot \mathrm{h}^{-1}$, annual production of briquettes is approx. 660 tons,

- variant B: double-shift work system, production line capacity of $250 \mathrm{~kg} \cdot \mathrm{h}^{-1}$, annual production of briquettes is approx. 1320 tons,

- variant C: triple-shift work system, production line capacity of $250 \mathrm{~kg} \cdot \mathrm{h}^{-1}$, annual production of briquettes is approx. 1980 tons,

- variant D: option additionally proposed by the authors, including installation of an additional briquetting machine on the production line and work in a three-shift system, production line capacity of $500 \mathrm{~kg} \cdot \mathrm{h}^{-1}$, annual production of briquettes is approx. 3960 tons. The following information characterizes the technology used and the premises for calculating the cost of briquette production:

- production line capacity $250 \mathrm{~kg} \cdot \mathrm{h}^{-1}$,

- humidity of sawdust used approx. 20-40\%,

- according to the company owner, one stere (st) bought from a sawmill usually weighs approx. $400 \mathrm{~kg}$, and can be used to produce approx. $250 \mathrm{~kg}$ of briquettes,

- the price of raw material per stere: 25 PLN,

- monthly repairs and maintenance: approx. PLN 1,500 (three-shift work system),

- monthly repairs and maintenance: approx. PLN 1,700 (three-shift work system for variant D), 
- production at the plant ran for 11 months per year, with one month intended for repairs and maintenance,

- sawdust drying costs: approx.: PLN 20.t- $\mathrm{t}^{-1}$ (according to information from the business owner),

- costs of renting the premises: PLN 5,289 per month (according to information from the business owner),

- packaging costs: PLN $37 \cdot \mathrm{t}^{-1}$ (determined based on information from the business owner); the packaging costs include: costs of purchasing plastic bags, pallets and foil for wrapping 50 bags per pallet,

- average electricity price in the period in question: PLN $0.66 \cdot \mathrm{kWh}^{-1}$ (adopted based on information from the business owner),

- average price of fuel in the period in question: diesel, PLN $5 \cdot 1^{-1}$

- eployee remuneration: PLN 14.7. $\mathrm{h}^{-1}$.

- calorific value of produced briquettes: $17 \mathrm{MJ} \cdot \mathrm{kg}^{-1}$. In addition, the following premises were made to calculate the cost of briquette production:

- price of a fully equipped technological line: PLN 560K,

- price of a fully equipped technological line with additional second briquetting press: PLN $710 \mathrm{~K}$,

- depreciation of technological line at $20 \%$ annually,

- installed electric power: $22 \mathrm{~kW}$, and $44 \mathrm{~kW}$ with a second briquetting machine,

- load on the equipment constituting the technological line: $80 \%$,

- telehandler (JCB 535-95): PLN 78K,

- depreciation of the telehandler at $18 \%$ annually,

- telehandler load: $60 \%$, and $70 \%$ in variant D.

The production process was based on a three-shift working system. One person worked on the line at each shift during the first two shifts. At the night shift, there were two people in the work station, in accordance with Polish labor law. Variant D assumes the work of two employees on all shifts.

All operating parameters were controlled automatically using a computer and integrated sensors. No binders, glues or synthetic ingredients were used for the production of briquettes.

\section{Results}

The studied production plant obtained raw material for the produced briquettes from three sawmills. Their average distance from the plant is $31.8 \mathrm{~km}$ and the tranport time is approx. 40 minutes (Table 1). The delivered sawdust was stored in a yard without roofing, directly by the briquette production hall. The sawdust was transported from the yard to the production line using a JCB 535-95 loader. 
Analysis of production...

Table 1.

Localities from which the raw material for the briquettes was supplied

\begin{tabular}{llcc}
\hline No. & Locality & $\begin{array}{c}\text { Distance from plant } \\
(\mathrm{km})\end{array}$ & $\begin{array}{c}\text { Expected transport time } \\
(\mathrm{min})\end{array}$ \\
\hline 1. & A1 - Wisła (sawmill) & 22.9 & 34.0 \\
\hline 2. & A2 - Istebna (sawmill 1) & 38.8 & 39.0 \\
\hline 3. & A3 - Istebna (sawmill 2) & 36.3 & 46.0 \\
\hline- & Geometric mean & 31.8 & 39.4 \\
- & Standard deviation & 8.6 & 6.0 \\
\hline
\end{tabular}

The following stages of the briquette production technology used by Brykiet-Pol2 can be distinguished:

- transport and storage of the raw material: yard without roofing,

- transport of sawdust to a self-propelled screw scraper: transfer of sawdust onto a conveyor belt, which transports it to subsequent production stages,

- cleaning sawdust from foreign objects (larger pieces of wood or metal waste) on a rotary screen unit,

- drying the raw material to appropriate humidity using a drum dryer fired with a batch of the sawdust (the burning process involves supplying moist material into the dryer drum, where a stream of warm air is fed at a temperature of approx. $85-95^{\circ} \mathrm{C}$ )

- screening the raw material to remove sand from dry sawdust,

- briquetting process,

- packing ready briquettes into bags (usually per $20 \mathrm{~kg}$ ).

The BRISUR 200 line included the following machines and devices:

- screw conveyor,

- 3 belt conveyors,

- sawdust cleaning magnet,

- rotary screen unit,

- boiler,

- boiler storage tank,

- dedusting cyclone,

- exhaust fan,

- drum dryer,

- exhaust ducts,

- briquetting machine (Brik Star 200),

- industrial scale

- pallet wrapping machine,

- control panel with computer,

- metal device frames.

The characteristics of wood briquette production are presented in Table 2. 
Filip Jasiczek, Dariusz Kwaśniewski

Table 2

Details of briquette production technologies for specific variants

\begin{tabular}{clccccc}
\hline \multirow{2}{*}{ No. Specification } & \multirow{2}{*}{ Unit } & \multicolumn{4}{c}{ Variant } \\
\cline { 3 - 6 } & & $\mathrm{A}$ & $\mathrm{B}$ & $\mathrm{C}$ & $\mathrm{D}$ \\
\hline 1. & Production line efficiency & $(-)$ & 1 & 2 & 3 & 3 \\
\hline 2. & No. of changes & $(\mathrm{h})$ & 8 & 16 & 24 & 24 \\
\hline 3. & Working hours per day & $(\mathrm{pcs})$. & 1 & 1 & 1 & 2 \\
\hline 4. & Working briquetting presses & $($ persons $)$ & 1 & 2 & 4 & 6 \\
\hline 5. & Employees & $(\mathrm{kW})$ & 22 & 22 & 22 & 44 \\
\hline 6. & Power installed on the line & $\left(\mathrm{t} \cdot\right.$ day $\left.^{-1}\right)$ & 2 & 4 & 6 & 12 \\
\hline 7. & & $\left(\mathrm{t} \cdot\right.$ month $\left.^{-1}\right)$ & 60 & 120 & 180 & 360 \\
8. & Briquette production (on average) & $\left(\mathrm{t} \cdot\right.$ year $\left.^{-1}\right)$ & 660 & 1.320 & 1.980 & 3.960 \\
\hline 9. & & & & & \\
\hline
\end{tabular}

Total costs of briquette production in Brykiet-Pol2 are shown in Table 3; Figure 1 shows their structure. Over the period in question, production costs for option A amounted to PLN $648.7 \cdot \mathrm{t}^{-1}$, for variant $\mathrm{B}, \mathrm{PLN} 491.5 \cdot \mathrm{t}^{-1}$, for variant $\mathrm{C} 458.7 \mathrm{PLN} \cdot \mathrm{t}^{-1}$ and for the proposed variant D, PLN 364.8 $\cdot \mathrm{t}^{-1}$. To compare, production costs in the company in 2009 were, respectively, for option A: PLN 373.0 $\cdot \mathrm{t}^{-1}$, B: PLN 355.2 $\cdot \mathrm{t}^{-1}$ and C: PLN 278.3· $\mathrm{t}^{-1}$ (Kwaśniewski, 2009). Please note that the costs obtained at the time did not include the cost of renting the premises (currently, depending on the production variant, they constitute between $4.4 \%$ and $14.8 \%$ of the total production costs of one ton of briquettes), the packaging costs (currently, depending on the production variant, they constitute between $5.7 \%$ and $10.1 \%$ of the cost of producing one ton of briquette) and the costs of in-house transport (currently, depending on the variant, they constitute between $12.5 \%$ and $17.2 \%$ of the total cost of producing one ton of briquette).

In another enterprise, the cost of producing one ton of briquettes in 2008 was PLN 219.4, and the plant produced briquettes from own raw material. At the time, the cost of obtaining the raw material was PLN 4.8 per ton, and the cost of chipping and milling was PLN $21.9 \cdot \mathrm{t}^{-1}$ (Kwaśniewski, 2008).

The briquette production process and costs can be compared against the costs of pellet production. The cost of producing one ton of pellets is PLN 269.85 $\cdot \mathrm{t}^{-1}$ (Kraszkiewicz et al., 2015). In this case, the largest costs, as much as $120 \mathrm{PLN} \cdot \mathrm{t}^{-1}$, constituted the purchase of the raw material; its share in 2015 amounted to as much as $44.5 \%$ (please note that in BrykietPol2, for the production of briquettes, these costs accounted for 15.4-27.4\%). As in the case of briquettes, the cost of pellet production should include the costs of fuel, electricity, depreciation of equipment included in the production line, costs associated with machinery repairs and maintenance, remuneration and the purchase of raw material mentioned above (sawdust, wood chips). As calculated by Kwaśniewski (2019), in the structure of pellet production costs, the lowest difference can be observed in the cost of drying the material (difference of approx. PLN 5.t $\mathrm{t}^{-1}$ ), equipment depreciation (difference of approx. PLN $31 \cdot \mathrm{t}^{-1}$ ), costs associated with repairs and maintenance of machinery (difference of approx. PLN $7 \cdot \mathrm{t}^{-1}$ ) and employee remuneration (difference of approx. PLN $15 \cdot \mathrm{t}^{-1}$ ). In the case of other components, the difference in production costs of pellets compared to the production of briquettes exceeded PLN 20:t $t^{-1}$ (Kwasniewski, 2019). 
Analysis of production...

Upon assessing the results obtained in the studied company, it can be stated that the production capacity of the technological line was the lowest for option A, amounting to 2 tons per day, and the highest - for option D (12 tons per day). Calculations for variants A and B were carried out to show the characteristic of the production line for single-shift and twoshift work systems. In fact, the plant works in a three-shift system, as shown in option C. With the plant's current equipment, this is the most advantageous solution.

The study proposed and presented a variant of calculations (D) for a doubled efficiency of the production line, using two briquetting presses. At that time, the cost of producing one ton of briquettes was lower by nearly PLN $94 \cdot \mathrm{t}^{-1}$, compared to variant C. It should be noted that the amount of finished product was twice as large. Increasing production and adopting such a solution can be an interesting alternative in the future expansion of the plant.

When assessing the structure of briquette production costs, it can be observed that the smallest share of costs per ton related to production line machinery repair and maintenance fees (variant $\mathrm{B}-2.8 \%$, variant $\mathrm{C}-2.0 \%$, variant $\mathrm{D}-1.4 \%$ ). Variant $\mathrm{A}$ is an exception, with the lowest costs per ton generated by with fees associated with drying the raw material, representing $3.1 \%$ of the total costs. The depreciation of the technological line had the largest share in the structure of production costs for variant A $(26.2 \%)$. The situation is different for variants $\mathrm{B}, \mathrm{C}$ and $\mathrm{D}$, in which the cost of purchasing sawdust have the largest share in the structure $(\mathrm{B}-20.3 \%, \mathrm{C}-21.8 \%, \mathrm{D}-27.4 \%)$. On the other hand, the costs of power consumption in the structure of briquette production costs are respectively: $\mathrm{A}-7.2 \%, \mathrm{~B}-9.5 \%$, $\mathrm{C}-10.1 \%, \mathrm{D}-12.7 \%$.

Table 3.

Details of briquette production technologies per individual variants

\begin{tabular}{|c|c|c|c|c|c|}
\hline \multirow{3}{*}{ No. } & \multirow{3}{*}{ Specification } & \multicolumn{4}{|c|}{ Variant } \\
\hline & & A & $\mathrm{B}$ & $\mathrm{C}$ & $\mathrm{D}$ \\
\hline & & \multicolumn{4}{|c|}{$\left(\mathrm{PLN} \cdot \mathrm{t}^{-1}\right)$} \\
\hline 1. & Sawdust purchase costs & 100.0 & 100.0 & 100.0 & 100.0 \\
\hline 2. & Premises rental costs & 96.2 & 48.1 & 32.1 & 16.0 \\
\hline 3. & Drying costs & 20.0 & 20.0 & 20.0 & 20.0 \\
\hline 4. & Depreciation of machinery & 169.7 & 84.8 & 56.6 & 35.9 \\
\hline 5. & Repairs and maintenance & 27.3 & 13.6 & 9.1 & 5.2 \\
\hline 6. & Power & 46.5 & 46.5 & 46.5 & 46.5 \\
\hline 7. & Employee remuneration & 58.8 & 58.8 & 78.4 & 58.8 \\
\hline 8. & Packaging costs & 37.0 & 37.0 & 37.0 & 37.0 \\
\hline 9. & In-house transport costs & 93.3 & 82.6 & 79.1 & 45.5 \\
\hline- & Briquette production costs & 648.7 & 491.5 & 458.7 & 364.8 \\
\hline
\end{tabular}




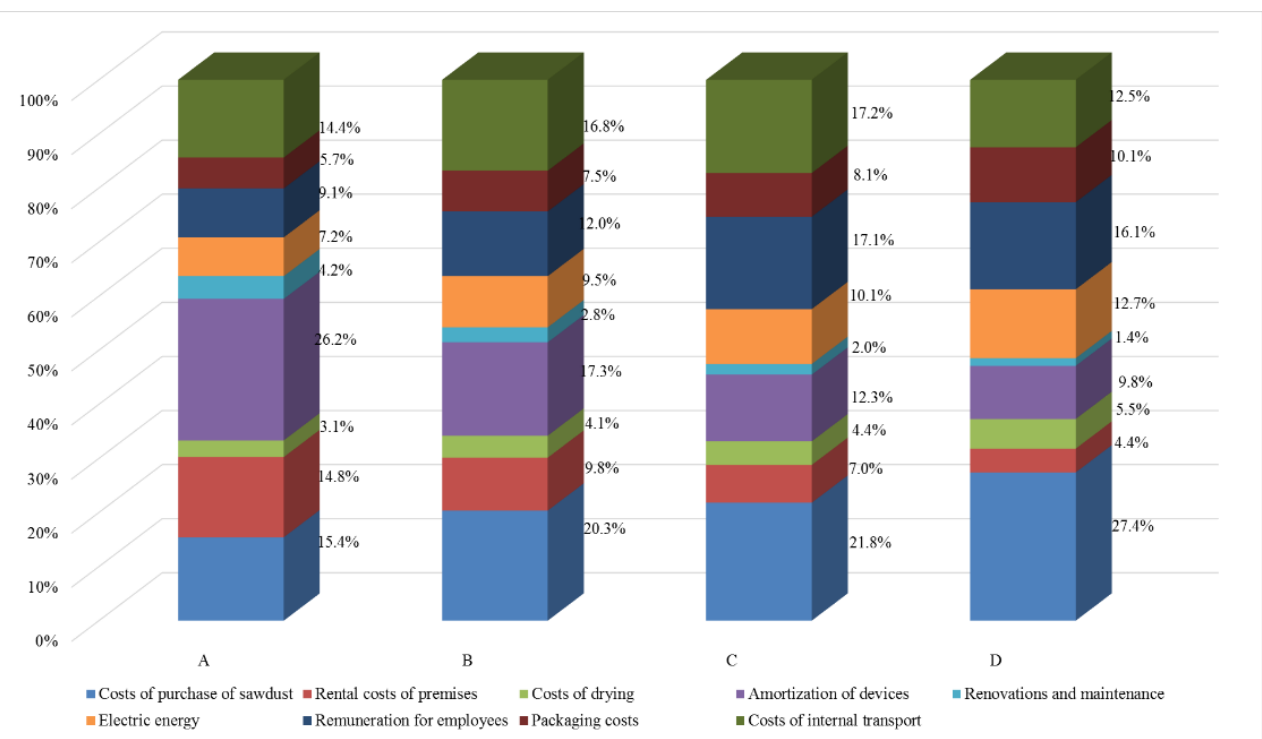

Figure1. Cost structure of producing wood briquettes

The distribution of produced briquettes in the studied company was also assessed. It should be remembered that the main challenge of distribution processes is their time consumption related to unspecified factors. This is due to the spatial distance between the producer and the consumer market, i.e. the briquette buyers.

Distribution is the last of the stages in the logistics chain. Its purpose is to deliver the finished product that meets the pre-arranged conditions to the end buyer in a timely manner (Dyczkowska, 2012).

When transporting biofuels, the permissible load capacity of vehicles and guidelines limiting the dimensions and cargo of the vehicle should be taken into account (Maj, 2015). In Poland, technical parameters of vehicles (dimensions, load capacity, permissible axle load) are regulated by the Regulation of the Minister of Infrastructure of December 31, 2002 on the technical conditions of vehicles and their necessary equipment, of December 31, 2002 (Journal of Laws [Dz.U.] 2015, item 305). According to the Regulation, the maximum length of the vehicle unit is $18.75 \mathrm{~m}$, the width of the vehicle may not exceed $2.55 \mathrm{~m}$ (for a vehicle intended to carry load at a certain temperature, if its side walls, together with thermal insulation, are no less than $45 \mathrm{~mm}$ each, the maximum length of the vehicle unit can be up to $2.60 \mathrm{~m}$ ). The Regulation stipulates the maximum height of the vehicle, which may not exceed $4 \mathrm{~m}$. This is important because the above restrictions must be taken into account when planning transports. Further restrictions resulting from the Act are:

- the total permissible mass for a vehicle unit with two-axle trailers: 18 tons, and for threeaxle trailers, 24 tons,

- in the case of a unit consisting of trailers and a semi-trailer transporting a 40-foot ISO container in combined transport, the total permissible mass is 44 tons. 
Analysis of production...

Table 4

Localities to which the distribution of wood briquettes was organized

\begin{tabular}{llcc}
\hline No. & Locality & $\begin{array}{c}\text { Distance from plant } \\
(\mathrm{km})\end{array}$ & $\begin{array}{c}\text { Expected } \\
\text { transport time }(\mathrm{min})\end{array}$ \\
\hline 1. & B1 - Nowa Ruda & 265 & 196 \\
\hline 2. & B2 - Bielsko-Biala & 35.8 & 35 \\
\hline 3. & B3 - Trzyniec (Czech Republic) & 10 & 15 \\
\hline 4. & B4 - Katowice & 84 & 80 \\
\hline 5. & B5 - Raciborz & 73 & 76 \\
\hline 6. & B6- Rybnik & 53 & 65 \\
\hline 7. & B7 - Pszczyna & 45 & 50 \\
\hline 8. & B8 - Zory & 39 & 37 \\
\hline- & Geometric mean & 52.1 & 54.3 \\
- & Standard deviation & 79.8 & 55.8 \\
\hline
\end{tabular}

The buyers of the produced briquettes in the analyzed enterprise were mainly dealers of solid biofuels and individual buyers. Please note that the studied company uses its MAN TGA 26-410 tractor only to supply raw materials, while briquette buyers organized transport on their own. For the company, it is convenient because it doesn't require additional means of transport, which significantly reduces the cost of distribution of the finished product. Table 4 demonstrates the locations to which distribution was organized and where briquettes were sold. The product was transported to a distance of 10 to $265 \mathrm{~km}$. The average distance was $52.1 \mathrm{~km}$, and the average transport time was approx. 54 minutes.

Information on briquette packaging:

- the produced briquettes were usually packed into $20 \mathrm{~kg}$ bags (please note that it is possible to pack them in bags of other dimensions),

- the bags were stacked on an industrial pallet $(800 \times 1200 \mathrm{~mm})$, at 50 bags at a time, which gives a total weight of $1000 \mathrm{~kg}$,

- the packed pallets were wrapped with several layers of foil,

- the finished load waited for transport in the yard without roofing,

- the truck could fit a maximum of 24 tons of briquettes (for the car with the highest load capacity transporting the briquettes).

The product was collected twice a week on average.

\section{Conclusions}

Based on the obtained research results, which shed light on the production costs of wood briquettes, and their structure, as well as on organization of their distribution, the following conclusions were drawn:

1. Throughout the year, sawdust used for the production of briquettes at the studied enterprise was purchased from three sawmills. The average distance from the plant from which the raw material came was $31.8 \mathrm{~km}$, and the transport time was approx. 40 minutes on average. On the other hand, briquettes were sold in $20 \mathrm{~kg}$ bags to eight locations. Their 
Filip Jasiczek, Dariusz Kwaśniewski

distribution distance was $52.1 \mathrm{~km}$ on average, and the transport time was approx. $54 \mathrm{~min}$ on average.

2. The most profitable variant of briquette production between July 2018 and July 2019 was variant $\mathrm{C}$, with a three-shift work system; the cost of producing one ton of briquettes was the lowest, amounting to PLN $458.7 \cdot \mathrm{t}^{-1}$.

3. The proposed briquetting variant $\mathrm{D}$, which included installing a second briquetting machine with a capacity of $250 \mathrm{~kg} \cdot \mathrm{h}^{-1}$, increased the annual briquette production from 1980 tons (variant C) to 3960 tons and reduced production costs to PLN $364.8 \cdot t^{-1}$.

4. For variants $\mathrm{B}, \mathrm{C}$ and $\mathrm{D}$, the lowest costs of briquette production per ton were associated with the repair and maintenance of the production line machinery. On the other hand, for option A, the lowest costs were associated with drying sawdust used for the production of briquettes.

5. The largest share in the structure of briquette production costs $(26.2 \%)$ was characteristic for the costs of depreciation of the technological line in variant A, where the technological line worked in a single-shift system and was not used effectively. On the other hand, in the remaining variants, the costs of purchasing sawdust had the largest share in the structure of production costs: $20.3 \%, 21.8 \%$ and $27.4 \%$ (variants B, C and D, respectively).

\section{References}

Dinesha, P., Shiva Kumar, A, Marc, A., Rosen, B. (2018). Biomass Briquettes as an alternative Fuel: A Comprehensive Review. Energy Technology, 7(5), 1-8.

Dubas, J. W., Grzybek, A., Kotowski, W., Tomczyk, A. (2004). Wierzba energetyczna - uprawa i technologie przetwarzania. Wyd. Wyższa Szkoła Ekonomii i Administracji w Bytomiu. ISBN 83-88587-71-4.

Dyczkowska, J. (2012). Logistyka zaopatrzenia i produkcji - wplyw na logistyke dystrybucji. Prace naukowe Politechniki Warszawskiej, Warszawa. Maszynopis.

Frączek, J. (red.) (2010a). Rozwój i technologie produkcji biopaliw statych. Przetwarzanie biomasy na cele energetyczne. Wyd. Polskie Towarzystwo Inżynierii Rolniczej. ISBN 978-83-917053-9-1. 161-173.

Frączek, J. (red.) (2010b). Optymalizacja procesu produkcji paliw kompaktowanych wytwarzanych z roślin energetycznych. Wyd. Polskie Towarzystwo Inżynierii Rolniczej. Kraków. ISBN 978-83930818-0-6

Frączek, J., Cieślikowski, B., Ślipek, Z. (2011). Ocena jakości biopaliw stałych kompaktowych część I: wymagania jakościowe. Autobusy, 10, 161-169.

Gostomczyk, W. (2012). Organizacja systemu logistycznego w produkcji i wykorzystaniu biomasy energetycznej. Logistyka, 4, 939-946.

Kachel-Jakubowska, M., Szpryngiel, M. (2014). Badania własne właściwości surowców biomasowych. $\mathrm{w}$ : Zrównoważone wykorzystanie surowców roślinnych i przemysłowych do produkcji peletów. 104-115.

Kowalik, P. (2002). Perspektywy paletyzacji biomasy w Polsce. Czysta Energia, 10, 14-15.

Kraszkiewicz, A., Lorencowicz, E., Kachel-Jakubowska, M. (2015). „Koszty produkcji peletów z biomasy roślinnej pochodzenia rolniczego”, Artykuły z Konferencji Innowacje w Zarządzaniu i Inżynierii Produkcji 2015, Zakopane, Polskie Towarzystwo Zarządzania Produkcją, I, 470-479. 
Analysis of production...

Kuś, L., Matyka, M. (2008). Produkcja biomasy na cele energetyczne jako alternatywny kierunek produkcji. Wieś Jutra, 8-9 (121-122), 8-10

Kwaśniewski, D. (2008). Technologie oraz koszty produkcji brykietów i peletów z wierzby energetycznej. Agricultural Engineering 5(103), 37-42.

Kwaśniewski, D. (2009). Analiza kosztów produkcji brykietów na przykładzie linii technologicznej typu BRISUR 200. Agricultural Engineering 5(114), 155-161.

Kwaśniewski, D. (2019). Logistic and economical preconditions for production of pellets from sawdust. Agricultural Engineering, 2(23), 5-14.

Maj, G. (2015). Warunki logistyki dystrybucji surowca do zakładów przetwórczych biomasy roślinnej. Logistyka 5, 357-364.

Muazu, R.I., Stegemann, J.A. (2015). Effects of operating variables on durability of fuel briquettes from rice husk and corn cobs. Fuel Processing Technology, 133, 137-145.

Niedziółka, I., Szymanek, M., Zuchniarz, A. (2007). Ocena właściwości energetycznych i mechanicznych brykietów z masy pożniwnej kukurydzy. Agricultural Engineering 7(95), 153-159.

Niedziółka, I., Szpryngiel, M., (2014). Możliwości wykorzystania biomasy na cele energetyczne. Agricultural Engineering 1(18), 155-164.

PN-EN 14961-1:2010: Biopaliwa stałe - Specyfikacje paliw i klasy-Część 1:Wymagania ogólne.

Sutrisno, W. Anggono, F,D. Suprianto, A.W. Kasrun, I.H. Siahaan. (2017). The effects of particle size and pressure on the combustion characteristics of cerbera manghasleaf briquettes. ARPN Journal of Engineering and Applied Sciences 12(4), 931-936.

Vaverkova, M.D., Radziemska M., Barton, S., Cerda, A., Koda E. (2018). The use of vegetation as a natural strategy for landfill restoration. Land Degrad Dev., 1-7.

Wróbel, M., Mudryk, K. (2010). Jakość biopaliw stałych. Przetwarzanie biomasy na cele energetyczne. Wyd. Polskie Towarzystwo Inżynierii Rolniczej. ISBN 978-83-917053-9-1.

\title{
ANALIZA TECHNOLOGII I KOSZTÓW PRODUKCJI BRYKIETÓW DRZEWNYCH I ICH DYSTRYBUCJA
}

\begin{abstract}
Streszczenie. W pracy dokonano analizy kosztów produkcji brykietów z trocin drzewnych w przedsiębiorstwie produkcyjno-handlowym Brykiet-Pol2, mającym siedzibę w Goleszowie leżącym w południowej części Polski. Dodatkowo przeanalizowano technologię produkcji, zaopatrzenie w surowiec i dystrybucję wyrobu gotowego. Koszty produkcji jednej tony brykietów dla czterech ocenianych wariantów wahały się od 364,8 PLN (wariant D) do 648,7 PLN (wariant A). W strukturze kosztów dominował zakup surowca oraz amortyzacja linii technologicznej. Najbardziej korzystnym z ekonomicznego punktu widzenia był realizowany w przedsiębiorstwie wariant produkcji $\mathrm{C}$ (koszty produkcji $458,7 \mathrm{PLN} \cdot \mathrm{t}^{-1}$ ) oraz proponowany wariant produkcji $\mathrm{D}$. Wtedy wykorzystywane były dwie brykieciarki, co zwiększyło wydajność produkcji i zmniejszyło jednostkowe koszty produkcji brykietów w systemie trzyzmianowym przez całą dobę.
\end{abstract}

Słowa kluczowe: brykiety, technologia produkcji, koszty produkcji, dystrybucja 